\title{
Labelling of individual ependymal areas in lateral ventricles of human brain: ependymal tables
}

\author{
Mitro $\mathrm{A}^{1}$, Lorencova $\mathrm{M}^{2}$, Kutna $\mathrm{V}^{3}$, Polak $\mathrm{S}^{2}$ \\ Institute of Neuroimmunology, Slovak Academy of Sciences, Bratislava, Slovakia. \\ stefan.polak@fmed.uniba.sk
}

\section{ABSTRACT}

Different types of ependymal areas were studied and labelled in the human brain lateral ventricle. Periventricular structures were included in coining the names of the ependymal areas because they represent a basic and stable part of brain nerve structures suitable for the sake of clarity of localization of the ependyma. The labelling of individual ependymal areas was composed from letters: "LV" (lateral ventricle); "E" (ependymal area) and letters for abbreviations of the closest periventricular structure, e.g. the septum pellucidum is "sp". The labelling for ependymal area over the septum pellucidum is thus "LvE-sp". The studied types of ependymal areas were arranged in so-called ependymal tables for cornu anterius, pars centralis, cornu inferius and cornu posterius of the human lateral ventricle. Labelling of individual ependymal areas allows for better localization and characterisation of these areas in future studies carried out by various methods (e.g. morphological, biological, molecular) and will prevent from using misnomers with different types of ependymal areas in norm as well as in pathology (Tab. 5, Fig. 6, Ref. 22). Text in PDF www.elis.sk.

KEY WORDS: human, central nervous system, lateral brain ventricle, ependymal areas, ependymal tables.

\section{Introduction}

The walls of the brain ventricles are lined with ependymal cells discovered by an eminent Czech scientist Jan Evangelista Purkyne in 1836. As it was shown that ventricle walls in human brain consist of three layers - ependymal layer, layer of subependymal glial fibres and layer of subependymal glial cells (1). In some regions, however, a distinguished layer of ependymal cells or subependymal cells is not present. An occurrence of small areas without ependyma is considered to be a normal phenomenon $(1,2)$. The ventricle wall lining in humans is also characterized by the presence of ependymal folding e.g. in region of vena thalamostriata (3).

One of the wide-spread view points about ependymal lining is that it is a homogenous population of ependymal cells. However, several works point to the heterogeneity of ependymal covering of the human brain walls, showing variability e.g. in form and number of cells in layers of ependyma. This fact might result from many uncertainties appearing at the evaluation of ependyma and probably are also caused by the lack of uniformed classification of different ependymal areas so that results of different authors may be compared only with certain difficulties $(2,4-9)$.

The surface of ependymal cells is in contact with cerebrospinal fluid (CSF). Ependymal cells monitor the quality of CSF and

${ }^{1}$ Institute of Neuroimmunology, Slovak Academy of Sciences, Bratislava, Slovakia, ${ }^{2}$ Institute of Histology and Embryology, Faculty of Medicine, Comenius University in Bratislava, Bratislava, Slovakia, and ${ }^{3}$ National Institute of Mental Health, Klecany, Czech Republic

Address for correspondence: $\mathrm{S}$. Polak, $\mathrm{MD}, \mathrm{PhD}$, Institute of Histology and Embryology, Faculty of Medicine, Comenius University in Bratislava, Sasinkova 4, SK-811 08 Bratislava, Slovakia. Phone: +421259357236. provide the underlying periventricular nervous tissue with information about various extracellular active signal molecules (10-16).

In our work, we attempted to develop a reproducible method of labelling individual ependymal areas of the walls of lateral ventricles, involving periventricular structures, i.e a method of coining the names for ependymal areas.

In this work ,ependyma“" is referred only to ependymal cells. The term ,ventricular wall“ is referred to as follows:

Ependymal cells that form the most inner part of ventricle wall,

Non-ependymal components localised in very close neighbourhood of ependymal cells (e.g. periventricular nerve and glial cells and other brain tissue components).

It is supposed, that the proposed method of naming the ependymal areas of human brain lateral ventricle will prevent misnomers when studied in norm as well as in pathology and in this manner to broaden our understanding of the role of individual ependymal areas.

\section{Material and methods}

Five human brains from individuals of both sexes aged from 27 to 60 years were used for the study (Tab. 1).

Tab. 1. Subjects' characteristics.

\begin{tabular}{cccc}
\hline Specimen & Age (years) & Sex & Cause of Death \\
\hline B1 & 27 & female & neoplasma renis \\
B2 & 42 & male & infarctus myocardii \\
B3 & 60 & male & embolia trunci pulmonalis \\
B4 & 69 & female & atherosclerosis \\
B5 & 73 & male & atherosclerosis \\
\hline
\end{tabular}



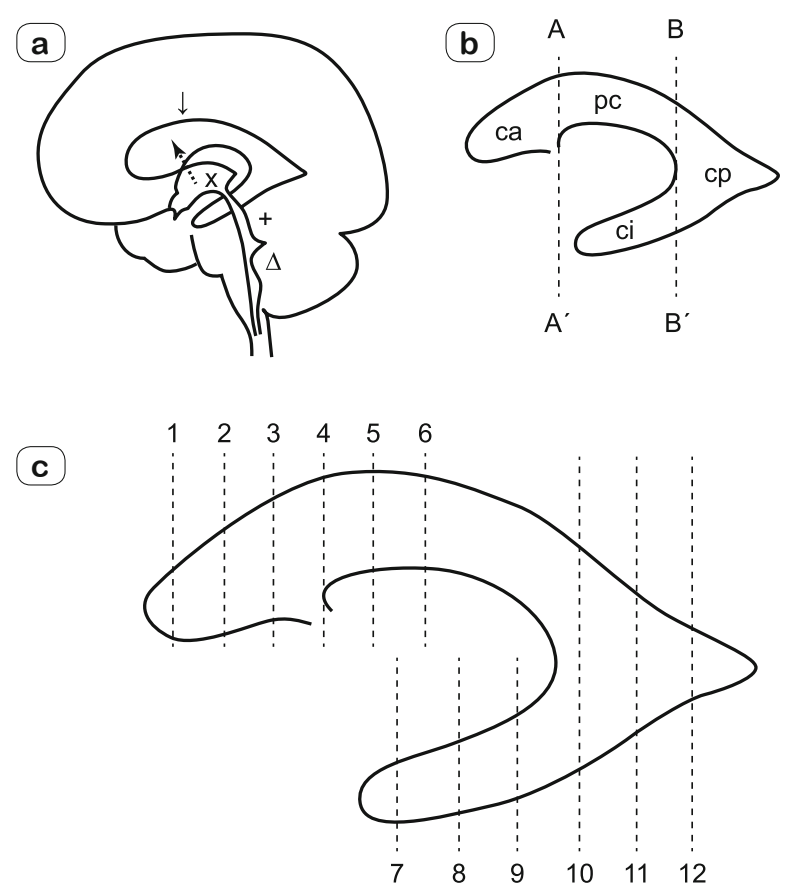

Fig. 1. a) Scheme of the brain ventricles $(\downarrow-$ lateral ventricle, $x$ - third ventricle, +- aquaeductus cerebri, $\Delta$ - fourth ventricle); b) Scheme of the lateral ventricle: $A-A^{\prime}-$ line placed on the dorsal end of the interventricular foramen, $\mathrm{B}^{-} \mathrm{B}^{\prime}$ - line running in place of merging of cornu inferior with cornu posterior (ca - cornu anterius; pc - pars centralis; ci - cornu inferius; cp - cornu posterius); c) Scheme of the lateral ventricle with histological sections 1-12 (sections 1-4 - cornu anterius, sections 5-6 - pars centralis, sections 7-9 - cornu inferius, sections 10-12 - cornu posterius).
The brains were removed by a standard procedure. In 24-48 hours after death, brains were fixed in $10 \%$ neutral formaldehyde. After 24 hours, fixation formalin was replaced with a fresh solution. The fixation of the brains lasted 30 days, then the brains were washed under running tap water for the next 24 hours. Fixed brains were sliced with an auxiliary device to obtain frontal brain slices equal in their thickness $(0.5 \mathrm{~cm})$.

The large brain slices were photographed by a standard technique. From large brain slices, small pieces of ventricle wall were excised and embedded in paraffin. Histological sections of 10 $\mu \mathrm{m}$ were stained with hematoxyline-eosine and cresyl-blue dyes.

\section{Results}

The brain ventricle system is composed of two lateral brain ventricles, third and fourth brain ventricles (Fig. 1 a).

The lateral ventricles (from the lateral view) resemble an irregular semi-circular cylinder, localized in each brain hemisphere and it can be divided to cornu anterius, pars centralis, cornu posterius and cornu inferius (Fig. 1 b).

The brains were cut in frontal sections and individual so-called large brain sections were drawn into a scheme and numbered from 1 to 12 (Fig. $1 \mathrm{c}$ ).

The wall of lateral ventricle, closer to the middle of the brain is referred to as inner wall (inw) and the wall more distant from the middle of the brain is referred to as external wall (exw). In some parts of the lateral ventricles, the dorsal wall (drw) is present.

\section{Cornu anterius}

In section 1, the "inw" is adjacent to genu corporis callosi (gcc). It is lined with multilayered ependyma. On the "exw" of cornu anterius, close to the caput nuclei caudati (canc), largely cuboidal ependyma is present (Tab. 1).

Tab. 2. Cornu anterius.

\begin{tabular}{|c|c|c|c|c|}
\hline \multirow{2}{*}{ Section } & \multirow{2}{*}{ Wall } & \multicolumn{2}{|c|}{ Periventricular structure } & \multirow{2}{*}{ Labbeling of ependyma } \\
\hline & & Name & Abbreviation & \\
\hline \multirow{2}{*}{1} & internal & genu corporis callosi & gcc & LvE-gcc \\
\hline & external & caput nuclei caudati & canc & LvE-canc \\
\hline \multirow[t]{2}{*}{2} & internal & $\begin{array}{l}\text { truncus corporis callosi } \\
\text { septum pellucidum } \\
\text { rostrum corporis callosi }\end{array}$ & $\begin{array}{l}\text { tcc } \\
\text { sp } \\
\text { rocc }\end{array}$ & $\begin{array}{l}\text { LvE-tcc } \\
\text { LvE-sp } \\
\text { LvE-rocc }\end{array}$ \\
\hline & external & $\begin{array}{l}\text { stratum subcallosum } \\
\text { caput nuclei caudati }\end{array}$ & $\begin{array}{c}\text { ssc } \\
\text { canc }\end{array}$ & $\begin{array}{l}\text { LvE-ssc } \\
\text { LvE-canc }\end{array}$ \\
\hline \multirow{3}{*}{3} & internal & $\begin{array}{l}\text { nuclei septi laterales } \\
\text { septum pellucidum } \\
\text { corpus fornicis }\end{array}$ & $\begin{array}{l}\mathrm{nsl} \\
\mathrm{sp} \\
\mathrm{cof}\end{array}$ & $\begin{array}{l}\text { LvE-nsl } \\
\text { LvE-sp } \\
\text { LvE-cof }\end{array}$ \\
\hline & external & $\begin{array}{l}\text { caput nuclei caudati } \\
\text { stratum subcallosum }\end{array}$ & $\begin{array}{l}\text { canc } \\
\text { ssc }\end{array}$ & $\begin{array}{l}\text { LvE-canc } \\
\text { LvE-ssc }\end{array}$ \\
\hline & dorsal & truncus corporis callosi & tcc & LvE-tcc \\
\hline \multirow{3}{*}{4} & internal & $\begin{array}{l}\text { corpus fornicis } \\
\text { foramen interventriculare }\end{array}$ & $\begin{array}{l}\text { cof } \\
\text { fiv }\end{array}$ & $\begin{array}{l}\text { LvE-cof } \\
\text { LvE-fiv }\end{array}$ \\
\hline & external & $\begin{array}{l}\text { stratum subcallosum } \\
\text { corpus nuclei caudati } \\
\text { stria terminalis } \\
\text { vena thalamostriata }\end{array}$ & $\begin{array}{c}\text { ssc } \\
\text { conc } \\
\text { st } \\
\text { vts }\end{array}$ & $\begin{array}{l}\text { LvE-ssc } \\
\text { LvE-conc } \\
\text { LvE-st } \\
\text { LvE-vts }\end{array}$ \\
\hline & dorsal & truncus corporis callosi & tcc & LvE-tcc \\
\hline
\end{tabular}




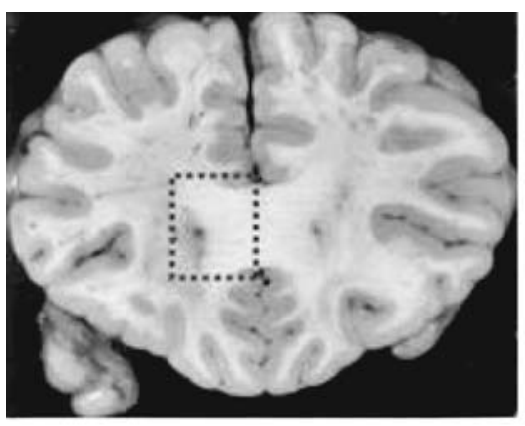

canc $\diamond^{g c c}$
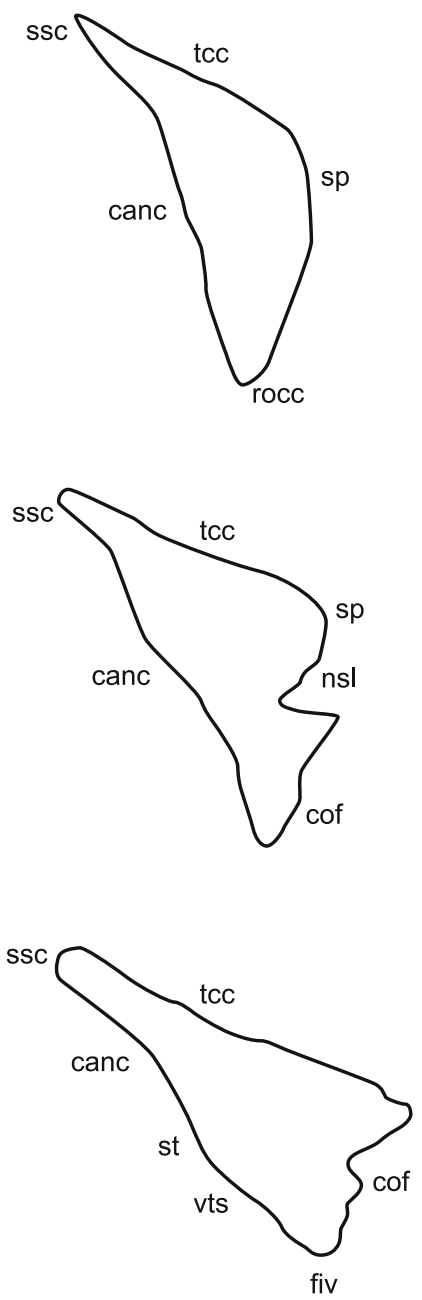

Fig. 2. Cornu anterius.
LvE-canc $\curvearrowright^{\text {LvE-gcc }}$
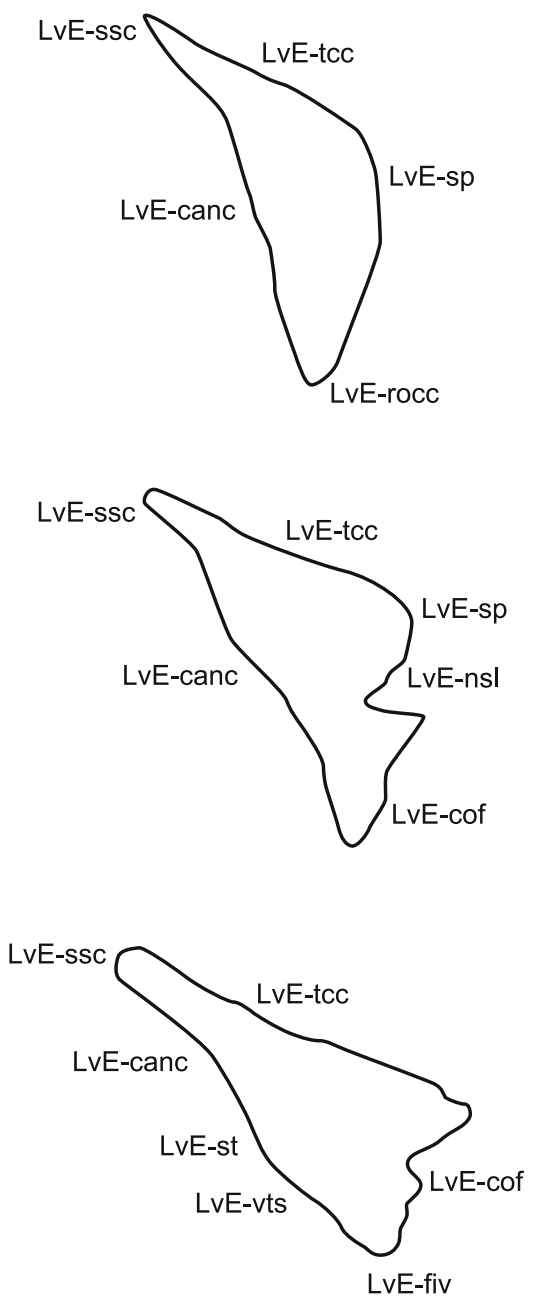

In section 2, the "inw" near truncus corporis callosi (tcc), septum pellucidim ( $\mathrm{sp}$ ), and rostrum corporis callosi (rocc), cuboidal to multilayered ependyma covers the wall of that part of cornu anterius. The ependyma of the "exw" adjacent to stratum subcallosum (ssc) and caput nuclei caudati (canc) is largely cuboidal.

In section 3 , the cross section of the ventricle has a triangular shape. The "inw" close to septum pellucidum (sp), nuclei septi laterales (nsl) and corpus fornicis (cof), is covered with cuboidal ependyma. The "exw" in region of caput nuclei caudati (canc) and stratum subcllosum (ssc) is covered with irregular cuboidal ependyma. The "drw" is covered with cuboidal ependyma in area of truncus corporis callosi (tcc).

In section 4, the "inw" adjacent to corpus fornicis (cof) and foramen interventriculare (fiv) the ependyma is one-layered to 

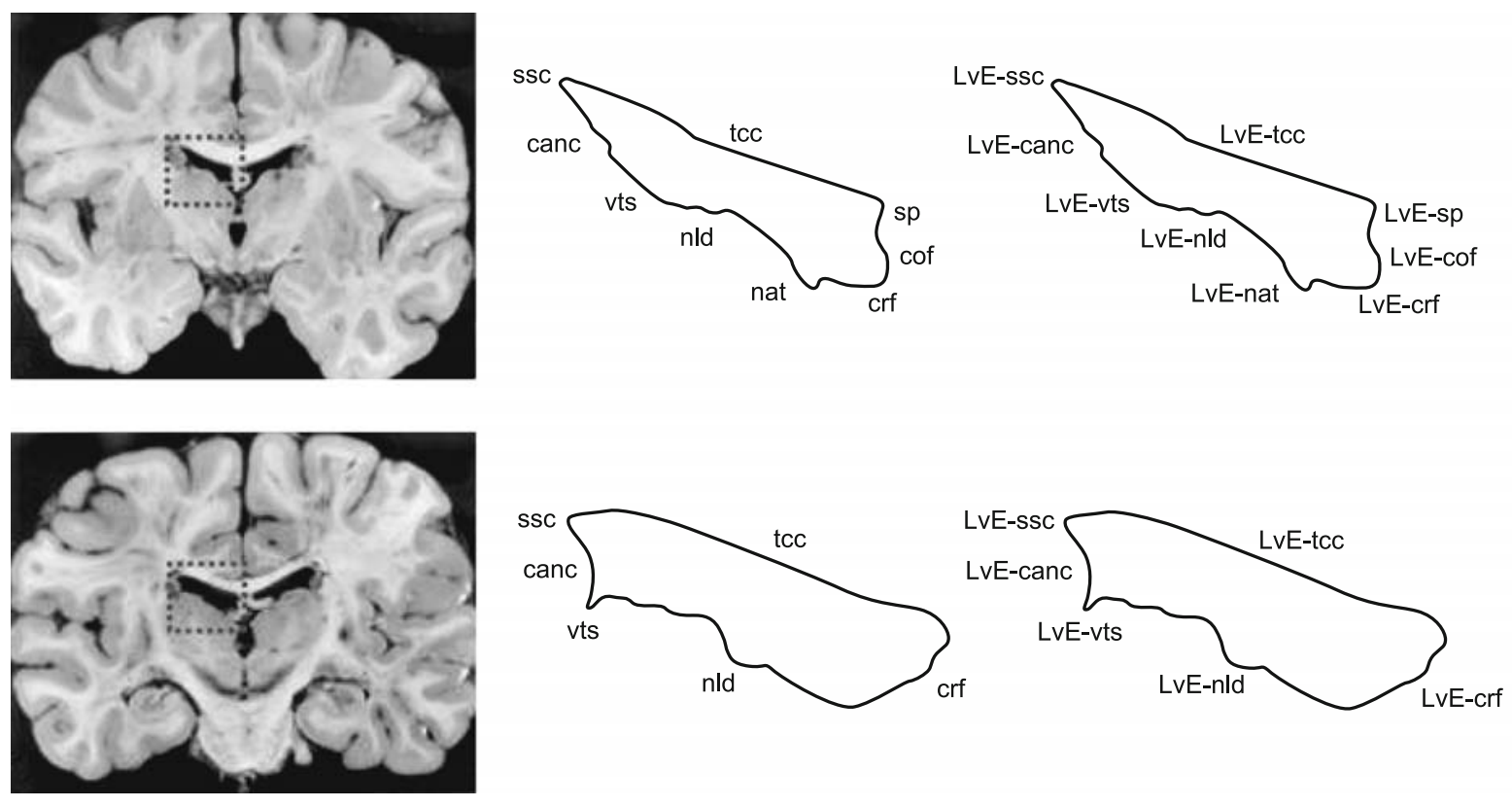

Fig. 3. Pars centralis.
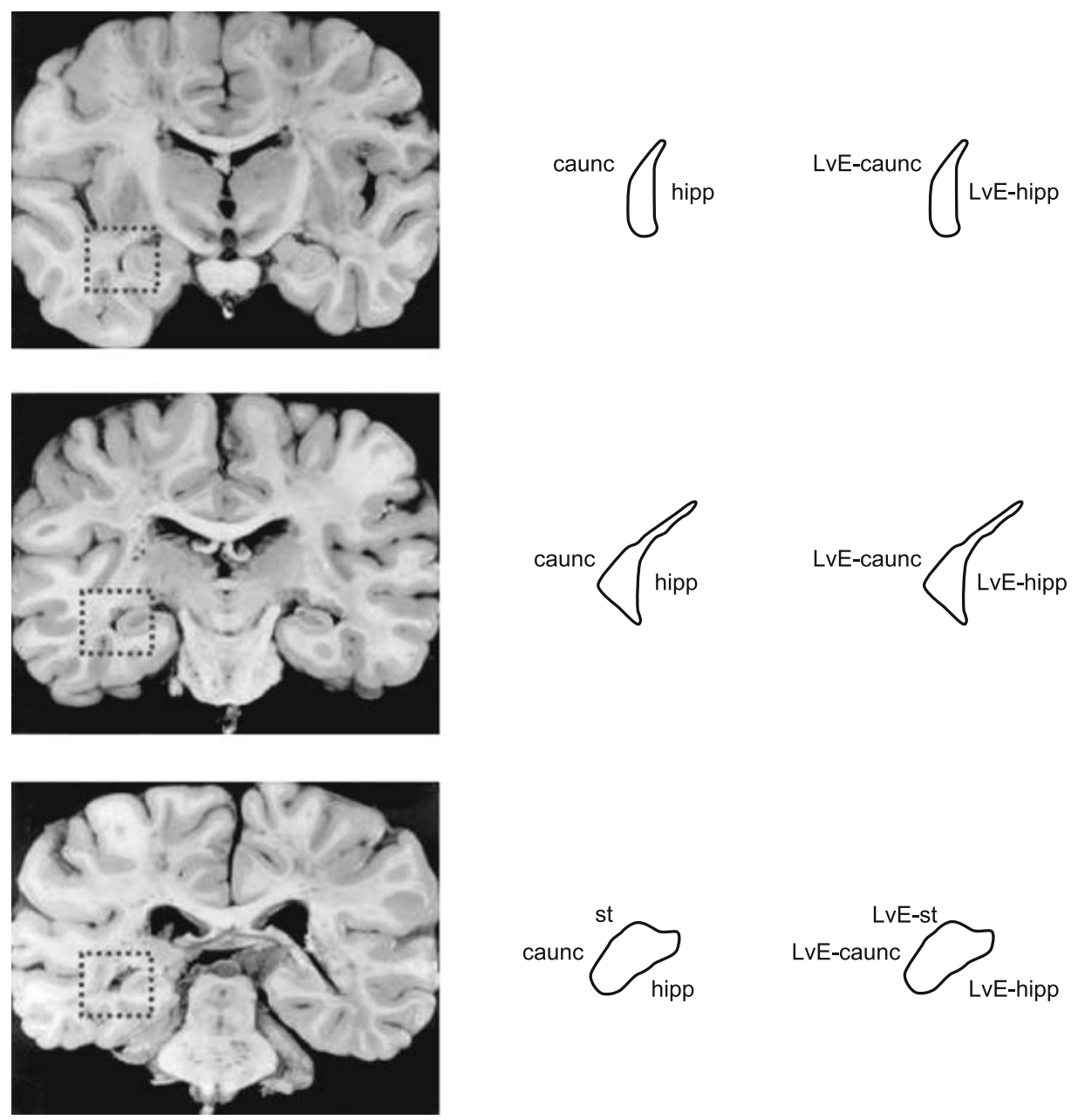

Fig. 4. Cornu inferius. 
Tab. 3. Pars centralis.

\begin{tabular}{|c|c|c|c|c|}
\hline \multirow{2}{*}{ Section } & \multirow{2}{*}{ Wall } & \multicolumn{2}{|c|}{ Periventricular structure } & \multirow{2}{*}{ Labbeling of ependyma } \\
\hline & & Name & Abbreviation & \\
\hline \multirow{3}{*}{5} & internal & $\begin{array}{l}\text { septum pellucidum } \\
\text { corpus fornicis } \\
\text { crus fornicis }\end{array}$ & $\begin{array}{l}\mathrm{sp} \\
\mathrm{cof} \\
\mathrm{crf}\end{array}$ & $\begin{array}{l}\text { LvE-sp } \\
\text { LvE-cof } \\
\text { LvE-crf }\end{array}$ \\
\hline & external & $\begin{array}{l}\text { stratum subcallosum } \\
\text { caput nuclei caudati } \\
\text { vena thalamostriata } \\
\text { nucleus lateralis dorsalis } \\
\text { nucleus anterior thalami }\end{array}$ & $\begin{array}{l}\text { ssc } \\
\text { canc } \\
\text { vts } \\
\text { nld } \\
\text { nat }\end{array}$ & $\begin{array}{l}\text { LvE-ssc } \\
\text { LvE-canc } \\
\text { LvE-vts } \\
\text { LvE-nld } \\
\text { LvE-nat }\end{array}$ \\
\hline & dorsal & truncus corporis callosi & tcc & LvE-tcc \\
\hline \multirow{3}{*}{6} & internal & crus fornicis & crf & LvE-crf \\
\hline & external & $\begin{array}{l}\text { stratum subcallosum } \\
\text { caput nuclei caudati } \\
\text { vena thalamostriata } \\
\text { nucleus lateralis dorsalis }\end{array}$ & $\begin{array}{c}\text { Ssc } \\
\text { canc } \\
\text { vts } \\
\text { nld }\end{array}$ & $\begin{array}{l}\text { LvE-ssc } \\
\text { LvE-canc } \\
\text { LvE-vts } \\
\text { LvE-nld }\end{array}$ \\
\hline & dorsal & truncus corporis callosi & tcc & LvE-tcc \\
\hline
\end{tabular}

Tab. 4. Cornu inferius.

\begin{tabular}{|c|c|c|c|c|}
\hline \multirow{2}{*}{ Section } & \multirow{2}{*}{ Wall } & \multicolumn{2}{|c|}{ Periventricular structure } & \multirow{2}{*}{ Labbeling of ependyma } \\
\hline & & Name & Abbreviation & \\
\hline \multirow{2}{*}{7} & internal & hippocampus & hipp & LvE-hipp \\
\hline & external & cauda nuclei caudati & caunc & LvE-caunc \\
\hline \multirow{2}{*}{8} & internal & hippocampus & hipp & LvE-hipp \\
\hline & external & cauda nuclei caudati & caunc & LvE-caunc \\
\hline \multirow[b]{2}{*}{9} & internal & hippocampus & hipp & LvE-hipp \\
\hline & external & $\begin{array}{l}\text { stria terminalis } \\
\text { cauda nuclei caudati }\end{array}$ & $\begin{array}{c}\text { st } \\
\text { caunc }\end{array}$ & $\begin{array}{c}\text { LvE-st } \\
\text { LvE-caunc }\end{array}$ \\
\hline
\end{tabular}

Tab. 5. Cornu posterius.

\begin{tabular}{|c|c|c|c|c|}
\hline \multirow{2}{*}{ Section } & \multirow{2}{*}{ Wall } & \multicolumn{2}{|c|}{ Periventricular structure } & \multirow{2}{*}{ Labelling of ependyma } \\
\hline & & Name & Abbreviation & \\
\hline \multirow{3}{*}{10} & internal & $\begin{array}{l}\text { hippocampus } \\
\text { crus fornix }\end{array}$ & $\begin{array}{c}\text { hipp } \\
\text { crf }\end{array}$ & $\begin{array}{l}\text { LvE-hipp } \\
\text { LvE-crf }\end{array}$ \\
\hline & external & tapetum & tap & LvE-tap \\
\hline & dorsal & splenium corporis callosi & $\mathrm{scc}$ & LvE-scc \\
\hline \multirow{3}{*}{11} & internal & $\begin{array}{l}\text { hippocampus } \\
\text { crus fornix }\end{array}$ & $\begin{array}{l}\text { hipp } \\
\text { crf }\end{array}$ & $\begin{array}{l}\text { LvE-hipp } \\
\text { LvE-crf }\end{array}$ \\
\hline & external & tapetum & tap & LvE-tap \\
\hline & dorsal & splenium corporis callosi & $\mathrm{scc}$ & LvE-scc \\
\hline 12 & external & tapetum & tap & LvE-tap \\
\hline
\end{tabular}

multi-layered. The "exw" close to stratum subcallosum (ssc), corpus nuclei caudati (conc), stria terminalis (st) and vena thalamostriata (vts) is lined with irregular flat, cuboidal one-layered to multi-layered ependyma. The "drw" in the area of truncus corporis callosi (tcc) is lined with cuboidal ependyma (Fig. 6 a).

Large brain sections of cornu anterius and ependymal table of cornu anterius are demonstrated in Figure 2 and Table 2.

\section{Pars centralis}

In section 5, the "inw" is covered by cuboidal ependyma localized adjacent to septum pellucidum (sp), corpus fornicis (cof) and crus fornicis (crf). The "exw" close to the stratum subcallosum (ssc), caput nuclei caudati (canc), vena thalamostriata (vt), nucleus lateralis dorsalis (nld) and nucleus anterior thalami (nat) is covered by cuboidal to columnar ependyma. The "drw" close to the truncus corporis callosi (tcc) is lined by cuboidal ependyma.

In section 6, the "inw" in the region of the crus fornicic (crf) is formed by irregular cuboidal ependyma. The "exw" adjacent to stratum subcallosum (ssc), caput nuclei caudati (canc), vena thalamostriata (vts) and and nucleus lateralis dorsalis (nld) is covered by cuboidal to columnar ependyma. The "drw" close to truncus corporis callosi (tcc) is lined by cuboidal ependyma (Fig. 3 and Tab. 3).

\section{Cornu inferius}

In section 7, the "inw" is adjacent to the hippocampus (hipp). The flat to cuboidal ependyma covers the ventricle wall in that part of cornu inferius. The "exw" close to cauda nuclei caudati (caunc) is lined with cuboidal ependyma. 


\section{5-271}
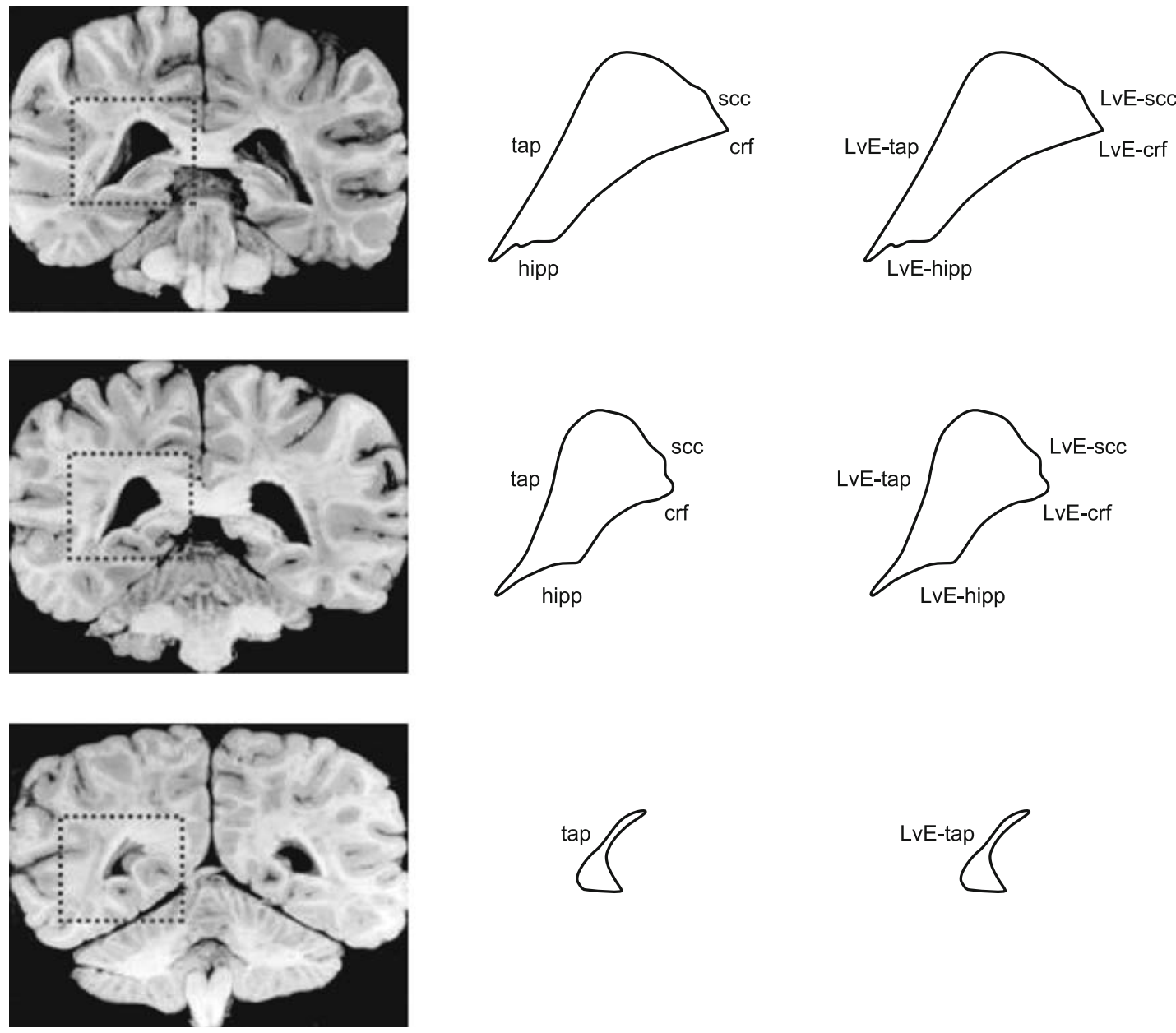
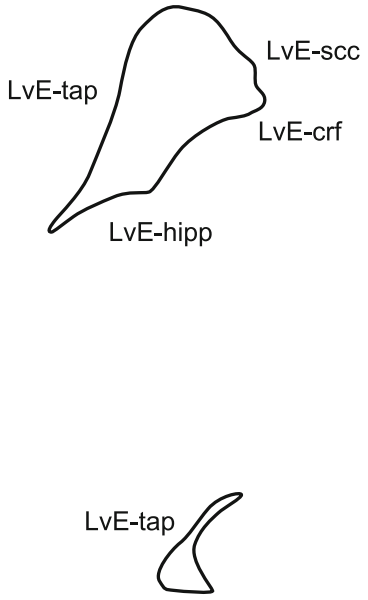

Fig. 5. Cornu posterius.
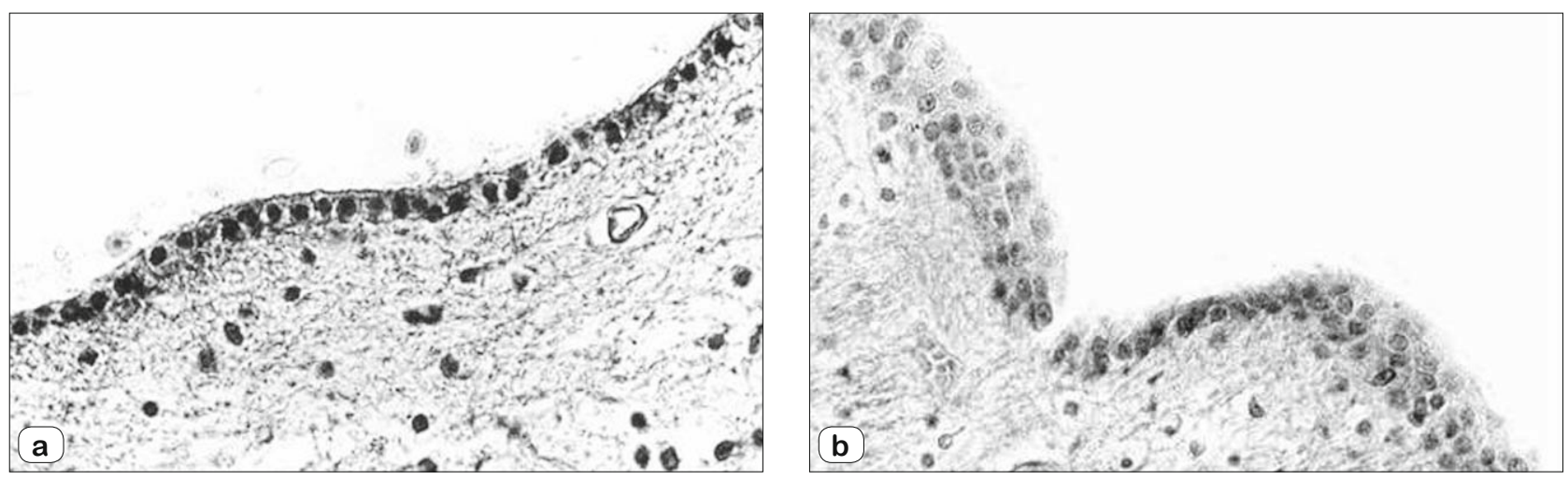

Fig. 6. Type of ependyma: a) cuboidal regular ependyma; b) multilayered ependyma.

In section 8, the "inw" is adjacent to the hippocampus (hipp) and is covered with cuboidal ependyma. The "exw" close to cauda nuclei caudati (caunc) is covered by cuboidal ependyma.

In section 9, the "inw" close to the hippocampus (hipp) is covered by multi-layered ependyma over. The "exw" adjacent to cauda nuclei caudati (caunc) and stria terminalis (st) is lined with one-layered to multi-layered ependyma (Fig. 4 and Tab. 4).

\section{Cornu posterius}

In section 10, the "inw" in the region of hippocampus (hipp) and crus fornix (crf) is covered with one-layered to multi-layered ependyma. The "exw" is close to the tapetum (tap) and lined with cuboidal ependyma. The "drw" close to the splenium corporis callosi (scc) is formed by multi-layered ependyma.

In section 11, the "inw" is close to hippocampus (hipp) and crus 
fornix (crf). The ependyma is multi-layered (Fig. 6 b). The "exw" close to the tapetum (tap) is lined by multi-layered ependyma.

In section 12, the "exw" close to the tapetum (tap) is covered by multi-layered ependyma (Fig. 5 and Tab. 5).

The ependymal Tables $2-5$ summarise the studied ependymal areas, including Latin names and abbreviations of periventricular structures as well as the labelling of ependymal areas.

Because it was found that e.g. cuboidal ependyma is present in all parts of the lateral ventricle, it was difficult to name the studied ependymal area only by its structure e.g. cuboidal ependyma of the lateral ventricle. It is suggested that coining the name for the wall of the studied parts (studied horn) of the ventricle as it is shown in ependymal tables, will help to localise better the individual ependymal areas.

\section{Discussion}

Labels for individual ependymal areas of the wall of the human lateral ventricle were not composed on the basis of their histological structures but rather on their localization relative to the closest periventricular nerve structures (17). These structures as basic parts of the brain are characterised by their stable localization.

It is known, that the periventricular nerve tissue belongs to the basic morphological structures of the brain (as such they are easily reproducible) and therefore they were included into the process of coining the names for individual ependymal areas of the walls of human lateral ventricle.

The principles of suggested method, (i.e. labelling of ependymal areas by means of periventricular brain nerve structures) can be applied also for other human brain ventricles in adults as well as during the development.

However, also other terms are used for naming the ependyma in the brain ventricles, e.g. neural type of ependymal cells, standard type ependyma cells, stromal ependymal cells, ependymal region, ependymal zone, specific subtypes of ependymal cells, tanycytes $(9,15,18,19)$.

It is expected that this work can assist in obtaining the answer to the question whether certain pathological changes of ependyma are related only to one or all types of ependymal areas of the walls of lateral ventricle in adult human brain.

It is possible to suppose that in spite of a very similar morphological arrangement of ependymal areas (ependymal cells) in the human lateral ventricles, these may differ, for example in the presence or absence of various receptors or active molecules on cell membranes (11).

In CSF and periventricular nervous tissue, various extracellular signal molecules (hormones, cytokines, growth factors) are present $(13,20-22)$. According to the place of effectivity of these molecules in ependymal areas located over various types of periventricular structures, they could react via different mechanisms.

\section{References}

1. Opalski A. Über lokate Unterscheide im Bau der Ventrikelwände beim Menschen. Zeitschrift fur die Gesamte Neurologie und Psychiatrie 1934; 149: 221-254.
2. Schimrigk K. Über die Wandstruktur der Seitenventrikel und des dritten Ventrikels beim Menschen. Z Zelfrosch 1966; 70: 1-20.

3. Friede RL. Uber Furchenfelder in den Wandung der Hirnventrikel. Acta Neurol 1953; 2: 179-184.

4. Fleischhauer K. Ependyma and subependymal layer. 1-46. In: Bourne $\mathrm{GH}(\mathrm{Ed})$. The structure and function of nervous tissue. Vol. VI. New York: Academic Press, 1972.

5. Mitro A (Ed). Ependyma and neurohormonal regulation. Bratislava: Veda, 1974: 1-320.

6. Leonhardt H. Ependym und zirkumventrikulare Organe. In: Oksche A, Vollrath L. (Eds). Handbuch der mikroskopischen Anatomie des Menschen. Nervensystem, 10. Teil: Neuroglia I. Berlin Heidelberg: Springer Verlag, 1980.

7. Del Bigio MR. The ependyma: a protective barrier between brain and cerebrospinal fluid. Glia 1995; 14 (1): 1-13.

8. Mitro A, Polák Š, Filipč́k P. Ependyma of the human brain ventricles. Giza: El-Meleigy Press, 2008: 1-100.

9. Del Bigio MR. Ependymal cells: biology and pathology. Acta Neuropathol 2010; 19 (1): 55-73.

10. Ermisch A, Rühle HJ, Landgraf R, Hess J. Blood-brain barrier and peptides. J Cereb Blood Flow Metab 1985; 5 (3): 350-357.

11. Wald A, Hochwald GM, Gandhi M. Evidence for the movement of fluid, macromolecules and ions from the brain extracellular space to the CSF. Brain Res 1978; 151 (2): 283-290.

12. Sarnat H.B. Histochemistry and immunocytochemistry of the developing ependyma and choroid plexus. Microsc Res Tech. 1998.

13. Martens DJ, Seaberg RM, van der Kooy D. In vivo infusions of exogenous growth factors into the fourth ventricle of the adult mouse brain increase the proliferation of neural progenitors around the fourth ventricle and the central canal of the spinal cord. Eur J Neurosci 2002; 16 (6): 1045-1057.

14. Reiber H. Proteins in cerebrospinal fluid and blood: barriers, CSF flow rate and source-related dynamics. Restor Neurol Neurosci 2003; 21 (3-4): 79-96.

15. Hauwel M, Furon E, Canova C, Griffiths M, Neal J, Gasque P. Innate (inherent) control of brain infection, brain inflammation and brain repair: the role of microglia, astrocytes, "protective" glial stem cells and stromal ependymal cells. Brain Res Rev 2005; 48 (2): 220-233.

16. Veening JG, Barendregt HP. The regulation of brain states by neuroactive substances distributed via the cerebrospinal fluid; a review. Cerebrospinal Fluid Res 2010; 7: 1.

17. Mitro A. Method of labelling of individual ependymal areas according to periventricular structures of the rat lateral brain ventricles. Biologia 2014; 69 (9): 1250-1254.

18. Mothe AJ, Tator CH. Proliferation, migration, and differentiation of endogenous ependymal region stem/progenitor cells following minimal spinal cord injury in the adult rat. Neuroscience 2005; 131 (1): 177-187.

19. Hamilton LK, Truong MK, Bednarczyk MR, Aumont A, Fernandes KJ. Cellular organization of the central canal ependymal zone, a niche of latent neural stem cells in the adult mammalian spinal cord. Neuroscience 2009; 164 (3): 1044-1056.

20. Chung K, Lee WT. Vasoactive intestinal polypeptide (VIP) immunoreactivity in the ependymal cells of the rat spinal cord. Neurosci Lett 1988; $95(1-3): 1-6$.

21. Alonso G, Phan V, Guillemain I, Saunier M, Legrand A, Anoal M, Maurice T. Immunocytochemical localization of the sigma(1) receptor in the adult rat central nervous system. Neuroscience 2000; 97 (1): 155-170.

22. Vígh B, Manzano e Silva MJ, Frank CL, Vincze C, Czirok SJ, Szabó A, Lukáts A, Szél A. The system of cerebrospinal fluid-contacting neurons. Its supposed role in the nonsynaptic signal transmission of the brain. Histol Histopathol 2004; 19 (2): 607-628.

Received February 6, 2018. Accepted February 23, 2018. 